\title{
Between analyser differences in chloride measurements and thus anion gap cause different interpretations of the acid-base balance.
}

Citation for published version (APA):

Geerts, N., Wlazlo, N., \& Scharnhorst, V. (2016). Between analyser differences in chloride measurements and thus anion gap cause different interpretations of the acid-base balance. Clinical Chemistry and Laboratory Medicine, 54(3), e81-e84. https://doi.org/10.1515/cclm-2015-0477

DOI:

10.1515/cclm-2015-0477

Document status and date:

Published: 01/03/2016

Document Version:

Accepted manuscript including changes made at the peer-review stage

Please check the document version of this publication:

- A submitted manuscript is the version of the article upon submission and before peer-review. There can be important differences between the submitted version and the official published version of record. People interested in the research are advised to contact the author for the final version of the publication, or visit the $\mathrm{DOI}$ to the publisher's website.

- The final author version and the galley proof are versions of the publication after peer review.

- The final published version features the final layout of the paper including the volume, issue and page numbers.

Link to publication

\footnotetext{
General rights

- You may freely distribute the URL identifying the publication in the public portal. follow below link for the End User Agreement:

www.tue.nl/taverne

Take down policy

If you believe that this document breaches copyright please contact us at:

openaccess@tue.nl

providing details and we will investigate your claim.
}

Copyright and moral rights for the publications made accessible in the public portal are retained by the authors and/or other copyright owners and it is a condition of accessing publications that users recognise and abide by the legal requirements associated with these rights.

- Users may download and print one copy of any publication from the public portal for the purpose of private study or research.

- You may not further distribute the material or use it for any profit-making activity or commercial gain

If the publication is distributed under the terms of Article $25 \mathrm{fa}$ of the Dutch Copyright Act, indicated by the "Taverne" license above, please 


\section{Letter to the Editor}

Nienke Geerts*, Nick Wlazlo and Volkher Scharnhorst

\section{Between analyser differences in chloride measurements and thus anion gap cause different interpretations of the acid-base balance}

DOI 10.1515/cclm-2015-0477

Received May 19, 2015; accepted July 24, 2015

Keywords: acidosis; anion gap; chloride; overestimation.

To the Editor,

The physiological approach is a serviceable method for interpreting acid-base disorders [1, 2]. The anion gap can be helpful in narrowing the differential diagnosis in a patient with metabolic acidosis. Metabolic acidosis due to the presence of an additional acid (endogenous or exogenous) usually results in an increased anion gap, whereas loss of bicarbonate typically results in a hyperchloremic metabolic acidosis, with a normal anion gap. Traditionally, the anion gap has been calculated from plasma values obtained on routine chemistry analysers in the laboratory [3]. With the availability of (bedside) electrolyte measurement in arterial blood gases (ABG), clinicians can evaluate metabolic acidosis rapidly by calculation of the anion gap from the ABG sample. Recently, we noticed that there were substantial differences between the anion gap obtained by ABG (ABL835, Radiometer), compared to the laboratory anion gap, calculated with concentrations obtained in plasma on the routine chemistry analyser (Cobas C-modules, Roche DX).

To assess the extent of the observed differences, electrolyte measurements and resulting anion gaps

Table 1: Comparison of mean electrolyte concentrations and the anion gap in arterial blood gas and venous plasma.

\begin{tabular}{lrrrrr}
\hline & ABG (whole blood) & Venous plasma & \multicolumn{1}{c}{$\boldsymbol{\Delta}$ Mean } & 95\% LoA & ICC agreement \\
\hline Sodium, mmol/L & $138.1 \pm 5.6$ & $137.6 \pm 5.2$ & 0.51 & $-4.24 ; 5.28$ & 0.945 \\
Potassium, mmol/L & $4.3 \pm 1.0$ & $4.3 \pm 1.1$ & -0.03 & $-0.74 ; 0.68$ & 0.968 \\
Chloride, $\mathrm{mmol} / \mathrm{L}$ & $105.1 \pm 6.0$ & $101.1 \pm 6.2$ & 3.99 & $-2.63 ; 10.61$ & 0.821 \\
Anion gap, $\mathrm{mmol} / \mathrm{L}$ & $15.9 \pm 5.6$ & $19.4 \pm 6.3$ & -3.47 & $-11.1 ; 4.2$ & - \\
Bicarbonate, $\mathrm{mmol} / \mathrm{L}$ & $17.1 \pm 4.8$ & - & - & - \\
\hline
\end{tabular}

Data are expressed as mean \pm standard error of the mean. Anion gap=sodium-(chloride+bicarbonate), using the sodium and chloride concentrations of arterial whole blood and venous plasma, respectively. ABG, arterial blood gas; ICC, intraclass correlation coefficient; LoA, limits of agreement.

*Corresponding author: Nienke Geerts, Catharina Hospital, Department of Clinical Chemistry, Michelangelolaan 2 Eindhoven 5602 ZA, The Netherlands, Phone: +31402398638 ,

E-mail: nienke.geerts@catharinaziekenhuis.nl

Nick Wlazlo: Department of Internal Medicine, Catharina Hospital, Eindhoven, The Netherlands

Volkher Scharnhorst: Department of Clinical Chemistry, Catharina Hospital, Eindhoven, The Netherlands; and Faculty of Biomedical Technology, Department of Chemical Biology, Eindhoven University of Technology, The Netherlands 

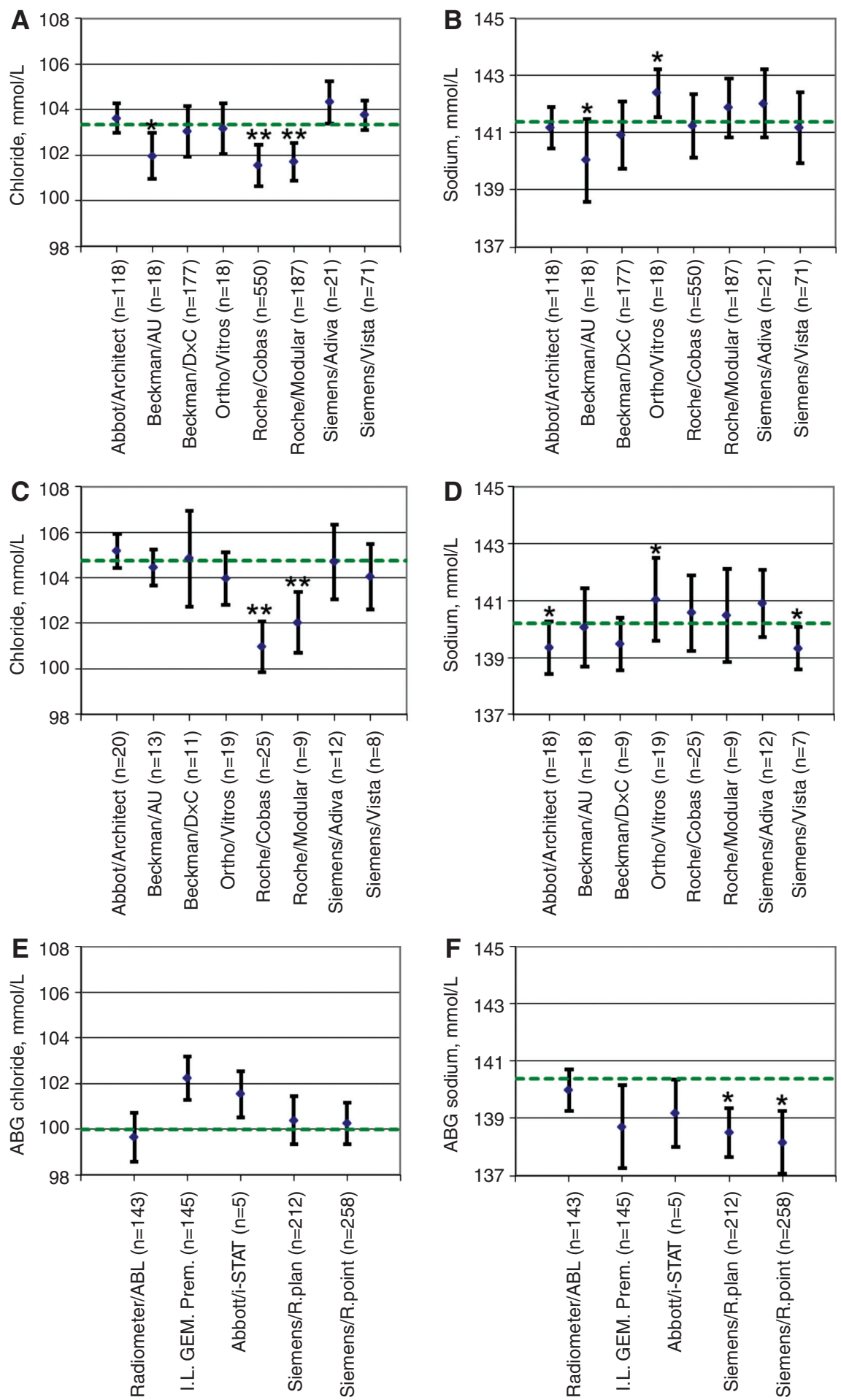

Figure 1: External control and master comparison results on different platforms.

(A) Mean concentration of yearly external electrolyte quality control samples (SKML 2014, The Netherlands) as measured on different chemistry analysers ( $n=$ number of measurements). The dotted line is the SKML-assigned mean reference concentration: Chloride concentrations. (B) as A: Sodium concentrations. (C) Mean concentration of external quality assessment survey with 20 fresh frozen, single donation samples (Mastercomparison 2014 STT consulting/UGent). The dotted line is the all manufacturer trimmed mean concentration: Chloride concentrations. (D) As C: Sodium concentrations. (E) Mean concentration of yearly external electrolyte quality control samples (SKML 2014, The Netherlands) as measured on different blood gas analysers ( $n=$ number of measurements). The dotted line is the SKML-assigned mean reference concentration: Chloride concentrations. (F) as E: Sodium concentrations. Differences between assigned reference concentration and measured concentration are significant at $p<0.05\left(^{*}\right)$; at $p<0.01\left(^{* *}\right)$. Error bars indicate standard errors of the mean. 
were compared in simultaneously drawn arterial blood and venous plasma samples of 529 patients that had visited the emergency department during the last 3 years. On average the anion gap was $-3.47 \mathrm{mmol} / \mathrm{L}$ lower (95\% LoA: -11.2 ; 4.1) when calculated from ABG values compared to venous measurements (Table 1). A closer look at the electrolyte concentrations indicated that, especially the chloride concentrations are significantly lower when measured in venous plasma samples (Table 1).

Of the 529 included patients, 269 (51\%) had a metabolic acidosis ( $\mathrm{pH}<7.35$; bicarbonate $<22 \mathrm{mmol} / \mathrm{L}$ ). The differences in anion gap were large enough to be clinical relevant. Twenty-five patients with a metabolic acidosis $(9 \%)$ had a normal anion gap according to ABG measurements, but an increased anion gap with plasma electrolytes. This could potentially result in a different differential diagnosis, and thus treatment. It should be noted that for both anion gaps ABG bicarbonate was used. While venous plasma bicarbonate is usually higher (approx. 1 $\mathrm{mmol} / \mathrm{L}$ ), calculating the anion gap with venous measurements exclusively will result in slightly lower anion gaps than reported here.

Ideally, the platform or chemistry analyser used, should not influence the measurement of electrolytes. In practice, even differences are found when the (average) concentrations of external quality control samples, measured on different platforms, are compared (Figure 1). Figure 1A indicates that both RocheCobas and Roche-Modular find significantly lower chloride concentrations than assigned (dotted line). The other analysers listed, besides Beckman/AU, do not show this deviation. The deviation of Beckman/AU may be due to the limited number of results. The observed difference of approximately $1.5 \mathrm{mmol} / \mathrm{L}$ in the external quality control does not fully explain the observed difference in the anion gap. However, when a comparison is made with 20 patient samples (Figure 1C) instead of control samples, the differences between Cobas modules and other platforms become more pronounced. The average difference of approximately $3.5 \mathrm{mmol} / \mathrm{L}$ is in agreement with the observed discrepancy in the anion gap. Figure $1 \mathrm{~B}$ and $\mathrm{D}$ show that a similar difference in control or patient samples is not observed for sodium; the average concentrations measured on Cobas modules agree well with the assigned (reference) values (dotted line). Figure $1 \mathrm{E}$ and $\mathrm{F}$ indicate that the blood gas analyser used (Radiometer; ABL835) measures chloride and sodium accurately.

Due to known difference between direct and indirect electrolyte measurements, it is recommended to adjust blood gas analyser results to make these comparable with direct measurements [4]. However, here the low chloride concentrations measured by the Cobas C-modules lead to higher anion gaps compared to ABG-anion gaps. In other words, even chemistry platforms (only indirect measurements) measure different chloride concentrations. For now, a correction factor is implemented to increase the chloride concentrations found on the routine chemistry analyser to a more factual concentration.

In conclusion, we describe a situation where the anion gaps, and thus clinical conclusions, depend on the analyser used. We are not the first to note differences in electrolyte concentration between ABG whole blood samples compared to venous plasma. Differences in sodium as well as chloride concentrations have been reported [5]. In this study, the observed difference could be traced back to consistently lower chloride concentrations in venous plasma samples compared to $\mathrm{ABG}$ and external quality control reference concentrations. For now, a practical solution to obtain a workable situation was chosen: a correction factor for chloride concentrations measured on the chemistry analysers has been implemented. However, this is neither desirable nor necessary, as others have reported similar problems $>10$ years ago [5]. Standardisation of sodium has been largely accomplished, it is now time for diagnostic companies to standardise chloride measurements as well.

Author contributions: All the authors have accepted responsibility for the entire content of this submitted manuscript and approved submission.

Financial support: None declared.

Employment or leadership: None declared.

Honorarium: None declared.

Competing interests: The funding organisation(s) played no role in the study design; in the collection, analysis, and interpretation of data; in the writing of the report; or in the decision to submit the report for publication.

\section{References}

1. Berend K, De Vries AP, Gans RO. Physiological approach to assessment of acid-base disturbances. N Engl J Med 2014;371:1434-45.

2. Adrogue HJ, Gennari FJ, Galla JH, Madias NE. Assessing acid-base disorders. Kidney Int 2009;76:1239-47.

3. Kraut JA, Madias NE. Serum anion gap: its uses and limitations in clinical medicine. Clin J Am Soc Nephrol 2007;2:162-74.

4. Ben Rayana MC, Burnett RW, Covington AK, D’Orazio P, Fogh-Andersen N, Jacobs E, et al. Recommendation for measuring 
and reporting chloride by ISEs in undiluted serum, plasma or blood. International Federation of Clinical Chemistry and Laboratory Medicine (IFCC). IFCC Scientific Division, Committee on Point of Care Testing and Working Group on Selective Electrodes. Clin Chem Lab Med 2006;44:346-52.
5. Morimatsu H, Rocktaschel J, Bellomo R, Uchino S, Goldsmith D, Gutteridge G. Comparison of point-of-care versus central laboratory measurement of electrolyte concentrations on calculations of the anion gap and the strong ion difference. Anesthesiology 2003;98:1077-84. 